\title{
Oculotrichodysplasia (OTD): a new probably autosomal recessive condition*
}

\author{
LÚCIA CECATTO-DE-LIMA $\dagger$, MARTA PINHEIRO \\ FREIRE-M A I A † \\ $\dagger$ Departamento de Genética, and $¥$ Secretaria de Estado da Saúde, Universidade Federal do Paraná, Curitiba, \\ Brazil.
}

SUMMARY A brother and sister, the offspring of first cousins, are described with retinitis pigmentosa, trichodysplasia (hypotrichosis and structural changes), dental anomalies, and onychodysplasia. This is a pure ectodermal dysplasia of the tricho-odonto-onychial subgroup, probably due to an autosomal recessive gene.

Ectodermal dysplasias ${ }^{12}$ form a large and complex nosological group with 131 conditions belonging to group $\mathrm{A}$, that is, characterised by signs in at least two of the following structures: hair, teeth, nails, and sweat glands. ${ }^{3-6}$

\section{Family history}

The condition was present in a brother and sister belonging to a sibship of 13 (six men and seven women) (fig 1). Twin boys, one of whom died in infancy, were described by the family as being 'identical'. The normal parents (of Portuguese and Indian origin) are first cousins $(F=1 / 16)$. The youngest member of the sibship (IV.13) has a left

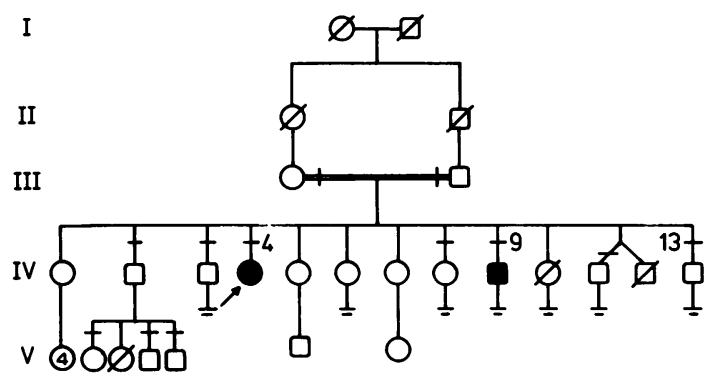

FIG 1 Pedigree of the family.

*This paper is dedicated to the memory of the late Professor Orlando Theodorico de Freitas, former director of the Center of Electronic Microscopy of our Univerșity.

Received for publication 29 May 1987. Accepted for publication 25 June 1987. cleft lip. All the other members of the family are normal.

\section{Case reports}

Case 1, the proband (IV.4) (fig 2), was born at term ㅇํㄱ on 15.7.57 after a normal pregnancy and delivery. $\vec{c}$ Birth weight and length were not noted (she was born at home). From birth she had had hypotrichosis.

Examination at the age of 28 years revealed a $\infty$ height of $154 \mathrm{~cm}$, a weight of $53 \mathrm{~kg}$, and a head circumference of $54.5 \mathrm{~cm}$. Interpupillary distance was $5.8 \mathrm{~cm}$, inner intercanthal distance $3.2 \mathrm{~cm}$, outer intercanthal distance $9 \cdot 1 \mathrm{~cm}$, internipple distance $19.5 \mathrm{~cm}$, and chest circumference at nipple level $88.0 \stackrel{\circ}{\frac{\circ}{\circ}}$ $\mathrm{cm}$. Some of these measurements are within normal limits and there is no reason to suspect that the others fall outside them. ${ }^{7}$

She had generalised hypotrichosis with sparse scalp, axillary, and pubic hair. Eyelashes were scanty and eyebrows were sparse in the distal twothirds. SEM analysis of scalp hair shafts revealed some structural changes in the orifices, peeling, scaling, dystrophic bulbs, and clubbing of free ends (fig 2). There was bilateral retinitis pigmentosa (the patient was almost blind in the left eye) and fragile and brittle finger and toenails; the teeth were few $\frac{9}{3}$ and carious with extensive extractions. The skin $\frac{7}{2}$ was dry and scaling.

Deciduous teeth were reported by the mother and $N$ maternal grandmother as having being small, pointed, and widely spaced, but they had erupted at 0 the normal time. As regards their number, now information could be obtained.

Normal findings included sweating, neurologicale status, hearing, locomotor apparatus, general $\Phi_{\mathscr{N}}$ health, dermatoglyphics, and chromosomes (nonbanding technique).

Case 2 (IV.9, fig 3) was born on 13.2.67 and was $\stackrel{\mathbb{D}}{\overparen{D}}$ examined at the age of 18 years. He was similar to $\frac{?}{\mathbb{D}}$ his affected sister, but his hypotrichosis was less $\varrho$ severe. He had slightly curly hair and, from the hair shafts analysed, folding and scaling were the only 8 

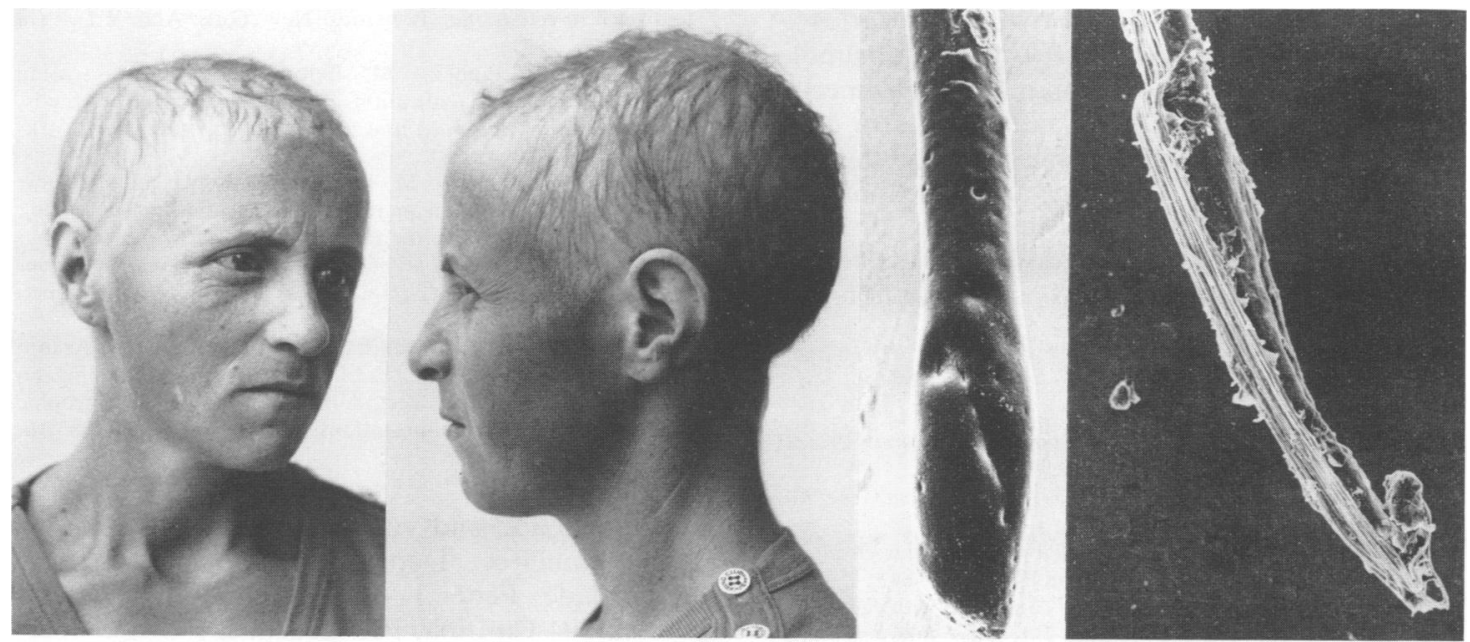

FIG 2 The proband aged 28 years. Note extensive scalp hypotrichosis and scanty eyebrows in their distal two-thirds. Eyelashes cannot be seen because they arc few, short, and thin. The skin colour is lighter on the scalp and around the ears because the patient always wears a scarf around her head. On the right, two hair shafts showing orifices, scaling, clubbing of free end, peeling, and dystrophic bulb.
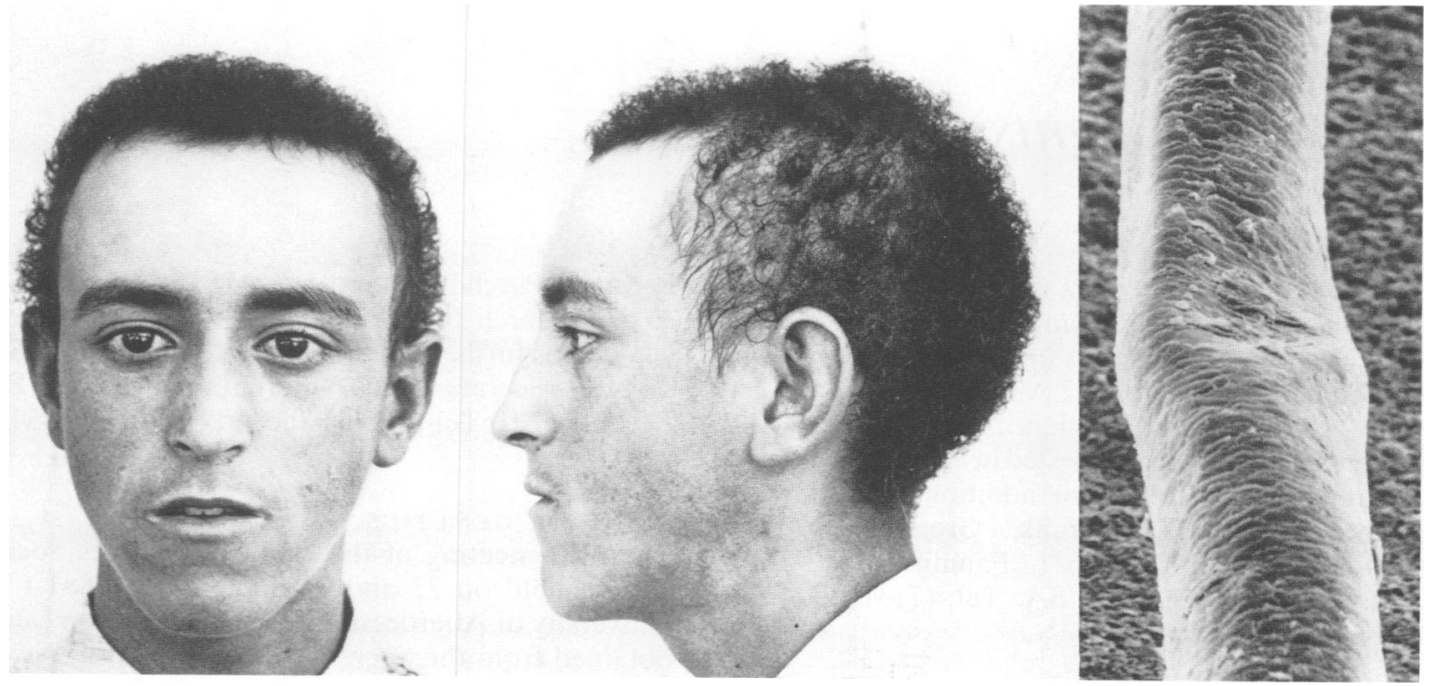

FIG 3 The proband's brother aged 18 years. Note scalp hypotrichosis. On the right, one of his hair shafts showing scaling and folding.

structural changes detected (fig 3). His bilateral retinitis pigmentosa was also less severe but this was probably because he was younger than his sister.

\section{Discussion}

This condition seems to be a hitherto undescribed ectodermal dysplasia belonging to group $\mathrm{A}^{1-6}$ and resulting from an autosomal recessive gene. It is more likely that retinitis pigmentosa is one of the signs of this condition than that we are facing a doubly homozygous pair of sibs (a similar situation was analysed before $^{8}$ ). 
The authors wish to thank Professor Carlos A Moreira and Dr Luiz A Zago for the ophthalmological evaluation, Professor Robin Mário Hofmeister for the SEM analysis of hair shafts, Professor Néria A Maia for the dermatoglyphic analysis, the National Council for Scientific and Technological Development (CNPq, Brasília) for financial support and Miss Irene Sedoski for secretarial assistance. The second and third authors are research fellows of $\mathrm{CNPq}$.

\section{References}

1 Freire-Maia N. Ectodermal dysplasias. Hum Hered 1971;21: 309-12.

${ }^{2}$ Freire-Maia N. Ectodermal dysplasias revisited. Acta Genet Med Gemellol (Roma) 1977;26:121-31.

${ }^{3}$ Freire-Maia N, Pinheiro M. Ectodermal dysplasias-a clinical and genetic study. New York: Alan R Liss, 1984.

${ }^{4}$ Freire-Maia N, Pinheiro M. Selected conditions with ectodermal dysplasia. In: Salinas CF, Opitz JM, eds. Interdisciplinary approach to ectodermal dysplasias. New York: Alan R Liss (in press).

${ }^{5}$ Freire-Maia N, Pinheiro M. Ectodermal dysplasias-some recollections and a classification. In: Salinas CF, Opitz JM, eds Interdisciplinary approach to ectodermal dysplasias. New York: Alan R Liss, (in press).

${ }^{6}$ Freire-Maia N, Pinheiro M. Ectodermal dysplasias-a review after 1984 with an overall analysis of all the conditions belonging to this nosologic group. Rev Brasil Genet 1987 (in press).

${ }^{7}$ Smith DW. Recognizable patterns of human malformation. Genetic, embryologic and clinical aspects. Philadelphia: Saunders, 1982.

${ }^{8}$ Pinheiro M, Freire-Maia N, Chautard-Freire-Maia EA, Araújo LMB, Liberman B. AREDYLD: a syndrome combining an acrorenal field defect, ectodermal dysplasia, lipoatrophic diabetes, and other manifestations. Am J Med Genet 1983;16 29-33.

Correspondence and requests for reprints to $\mathrm{Dr}$ Marta Pinheiro, Departamento de Genética, Universidade Federal do Paraná, Caixa Postal 19071, 81504 Curitiba, PR, Brazil.

\section{Announcements}

SYMPOSIUM ON WILLIAMS SYNDROME

A medical and scientific symposium on the aetiology, diagnosis, natural history, or treatment of Williams syndrome will be held on 2 August 1988 in Salt Lake City, Utah. Medical, scientific, or other health related professionals interested in Williams syndrome are invited to attend. For additional information, please contact Dr Frank Greenberg, Texas Children's Hospital, 6621 Fannin, Box 3-210, Houston, Texas 77030, USA. Tel: (713) 791-4774.

NINTH INTERNATIONAL CONGRESS ON PRE- AND PERINATAL PSYCHOLOGY AND MEDICINE The Ninth International Congress on Pre- and
Perinatal Psychology and Medicine will be held on 26 to 31 March 1989 at the Hilton Hotel, Jerusalem, Israel. For further information, please contact ISPP Congress Secretariat, c/o International Ltd, PO Box 29313, 65121 Tel-Aviv, Israel. Tel: (03) 654541.

CLINICAL GENETICS SOCIETY

The next meeting of the Clinical Genetics Society will be held on 22 and 23 September 1988 at the University of Aberdeen. Further information can be obtained from the Secretary, Professor N C Nevin, Department of Medical Genetics, Belfast City Hospital, Lisburn Road, Belfast BT9 7AB, Northern Ireland. 